\title{
SAUSSURE APÓS UM SÉCULO: A PROBLEMÁTICA DO OBJETO DA LINGUÍSTICA*
}

\section{SAUSSURE AFTER A CENTURY: THE PROBLEM OF THE OBJECT OF LINGUISTICS}

\author{
Maria Iraci Sousa Costa** \\ Universidade Federal de Santa Maria, Programa de Pós-Graduação em Letras, Laboratório \\ Corpus, Santa Maria, RS, Brasil
}

\begin{abstract}
Resumo: Neste artigo, temos o objetivo de desenvolver uma reflexão sobre a natureza do objeto da Linguística, considerando a complexidade do corpus saussuriano. Tomaremos como ponto de partida não só a problemática sobre a natureza do objeto da Linguística tal como é concebida no Curso de Linguística Geral, obra que alçou a Linguística no domínio da ciência, mas também como essa problemática é abordada tanto no manuscrito saussuriano "Nature de l'objet en linguistique" quanto nas diferentes ediçôes publicadas dos manuscritos de Ferdinand de Saussure encontrados em 1996, a saber, a ediçẫo francesa Écrits de linguistique générale (2002), e também a edição suíça Science du Langage - De la double essence du langage (2011).
\end{abstract}

Palavras-chave: objeto; corpus saussuriano; linguística.

Abstract: In this article, we aim to develop a reflection upon the nature of the object of Linguistics considering the complexity of Saussurean corpus. Our starting point is the problem of the nature of the object of Linguistics as conceived in Course in General Linguistics , a work that took Linguistics into science, and also how this issue is addressed in Saussurean manuscript Nature de l'objet en linguistique, as well as in different editions of Ferdinand de Saussure's manuscripts found in 1996, namely, the French edition of Écrits de linguistique générale (2002), and the Swiss edition, Science du Langage - De la double essence du langage (2011).

Keywords: object; Saussurean corpus; Linguistics.

\footnotetext{
* Agradeço à professora Amanda Eloina Scherer, minha eterna orientadora, pela leitura atenta e orientação precisa de sempre.

** Pós-doutoranda pelo Programa de pós-Graduçâo em Letras da Universidade Federal de Santa Maria, sob supervisão da Professora Dr. Amanda Eloina Scherer. Bolsista DOCFIXFAPERGS/CAPES.
} 


\title{
A definiçấo do objeto da Linguística: (re)leituras e recepçóes
}

\author{
Por que escolheu, dentro de um domínio tão vasto \\ e tão prometedor, um objeto tão árduo?
}

(BENVENISTE, 2005, p. 36).

O presente artigo é parte do estudo que estamos desenvolvendo em nosso estágio de pós-doutorado, sob supervisão da Professora Dr. Amanda Eloina Scherer. Temos nos dedicado a refletir sobre o legado do linguista Ferdinand de Saussure, considerando a complexidade do corpus saussuriano, o qual compreende notas manuscritas, ediçóes das notas manuscritas, obras publicadas por Saussure e também as publicadas em seu nome, entre outros. No presente artigo, recortamos como mote para a nossa reflexão a problemática sobre o objeto da Linguística, tendo em vista a sua importância para a constituição da Linguística enquanto ciência. Uma primeira versão deste artigo já foi submetida à publicação em um livro organizado em homenagem ao mestre genebrino pela proximidade dos 100 anos de publicação do Cours de Linguistique Générale (1916).

De fato, quase 100 separam-nos da publicação do Cours de Linguistique Générale (CLG) e, curiosamente, continua a colocar-nos questionamentos. Essa obra, que não foi publicada pelo mestre genebrino Ferdinand de Saussure, mas cuja autoria é a ele atribuída, contribuiu para colocar a Linguística no domínio das ciências ao definir-lhe um objeto. Trata-se de uma obra póstuma que não tinha a pretensão de vir a tornar-se uma publicação por aquele a quem se atribui sua autoria. Passado quase um século desde sua publicaçáo, a permanência da discussão em torno do CLG pode ser relacionada a vários fatores, como, por exemplo, a complexidade do seu processo de ediçáo, ao lugar que essa obra ocupou na história da Linguística, bem como às diferentes (re)leituras realizadas em diferentes momentos.

Como sabemos, Ferdinand de Saussure não publicou a obra conhecida como CLG. O título conferido a essa obra é homônimo ao curso ministrado por Saussure a um diminuto público, ao longo de três anos, na Universidade de Genebra, entre 1907 e 1911. De fato, a obra editada e organizada a partir de notas referentes ao curso por Charles Bally e Albert Sechehaye publicada em 1916 "suscitou interesse e críticas sem que ninguém visse nele um barril de pólvora suscetível de ser ameaça à tradição universitária" (NORMAND, 2009, p. 16).

Contemporaneamente ao movimento estruturalista, começaram a 
ser publicadas tanto ediçóes críticas do CLG, quanto as fontes consultadas pelos editores que apontavam várias divergências, como, por exemplo, ediçôes críticas de Robert Godel (1957) e a de Rudolf Engler (1968). Apesar das controvérsias em relação à forma como o Cours foi concebido e mesmo após as inúmeras publicações das fontes manuscritas do CLG,

[...] esse texto que o "mestre" não escreveu, não achou por bem escrever, a história da linguística e, mais amplamente, do pensamento moderno (aquele das ciências sociais), dele se apropriou, tornando-o, durante todo o período dito "estruturalista", um emblema e uma referência (NORMAND, 2009, p. 20 , grifos da autora).

Em meio ao movimento estruturalista que tomou força na Europa a partir década de 1950, foi constituído um corte epistemológico a partir da publicaçáa do CLG, e Saussure foi aclamado o precursor da ciência linguística. Nesse movimento, Saussure foi aclamado o "pai" do estruturalismo, ainda que a noção de estrutura seja quase ausente em sua obra e não tenha sido tomada como sinônimo de "sistema". Além disso, é importante considerar que o título de estruturalista foi atribuído à Saussure a posteriori, de modo que náo poderíamos, sob pena de cair no anacronismo, afirmar que o mestre genebrino intitulava a si próprio como estruturalista.

No seio desse movimento intelectual que passou a considerar a Linguística um modelo de cientificidade para as ciências humanas, tomando como referência o CLG, muitos autores consideram que o mérito da contribuição saussuriana é atribuído principalmente por definir o objeto da Linguística e estabelecer um método próprio, mostrando ao linguista o que ele fazia sem saber. O corte epistemológico promovido por Saussure, ao definir o objeto da Linguística, separando langue et parole, a parte social e a parte individual na linguagem, constitui uma das mais importantes dicotomias saussurianas. Ao eleger a langue como objeto da Linguística, dada as suas preocupaçóes epistemológicas, a leitura frequentemente realizada é a de que Saussure, ao deixar de fora as questôes relativas à parole, estaria afastando também as questôes relativas ao sujeito e ao sentido na linguagem. Cabe ressaltar que as críticas em relação às "exclusóes" de Saussure são acentuadas quando o movimento estruturalista entra em crise, e o otimismo cientificista que acreditava encontrar na Linguística o modelo para a cientificidade das ciências humanas passa a ser questionado (PAVEL, 1990). Passado esse momento de efervescência, tomada uma certa distância temporal e, ainda, considerando-se o desenvolvimento das ciências da linguagem, "para a maior parte dos linguistas de hoje, o momento saussuriano é datado e, por isso 
mesmo, ultrapassado, qualquer que tenha sido sua consequência histórica" (NORMAND, 2009, p. 18).

Mesmo após a crise do movimento estruturalista, no seio do qual Saussure foi aclamado o precursor, ainda que não tenha tratado da noção de estrutura, o CLG continua na ordem do dia. Depois de toda essa expectativa em torno de a Linguística ter-se mostrado apenas uma "miragem linguística" (PAVEL, 1990), a problemática em torno do CLG continua a ser debatida, especialmente à luz dos manuscritos saussurianos encontrados na década de 1990. Hoje já não se espera mais encontrar na Linguística a chave para a cientificidade das ciências humanas a partir do CLG; discute-se, entre outras coisas, a leitura estruturalista realizada sobre o CLG, a importância dessa obra para a história da Linguística, a problemática sobre a forma como o CLG foi concebido, a sua relação com as notas manuscritas de Saussure e dos alunos e também a edição das notas saussurianas.

Neste artigo, a nossa proposta é desenvolver uma reflexão sobre um dos aspectos mais importantes do CLG - a nosso ver -, que contribuiu para colocá-lo na ordem das discussóes, a saber, a natureza do objeto em Linguística. Para desenvolver nossa reflexão, consideramos, além do CLG, o manuscrito saussuriano "Nature de l'objet en linguistique", o qual faz parte de "De la double essence du langage", bem como as duas ediçóes publicadas dos manuscritos encontrados em 1996, a edição francesa Écrits de linguistique générale (2002), editada e organizada por Simon Bouquet e Rudolf Engler, e a ediçáo suíça Science du Langage - De la double essence du langage (2011), editada por René Amacker.

A nossa proposta não é realizar um estudo comparativo para apontar as faltas, mas compreender a problemática saussuriana, considerando a heterogeneidade do corpus, sem exclusóes nem hierarquias, pois pensamos que a obra de Saussure deve ser entendida como um todo, visando, com isso, a uma melhor compreensão do empreendimento saussuriano. Além disso,

[...] consideramos ser inútil e injusto banir e rejeitar o que quer que seja (inclusive o CLG) e que é totalmente ilegítimo considerar que as fontes manuscritas estariam condenadas à incompreensão e que só serviriam, in fine, para reforçar a posição e poderio do CLG. Ao contrário, é preciso, de maneira vigilante, crítica, mas respeitosa da história, tomar cada tipo de documento pelo que ele é, recolocá-lo em seu contexto de origem e tentar, na medida do possível, reconstruir o pensamento saussuriano, em sua progressão e sua coerência de conjunto - ou seja: assumir a natureza forçosamente interpretativa de nosso trabalho de pesquisa e permitir ao conflito de 'interpretaçóes' que pode decorrer disso fazer viver seu potencial heurístico (BULEA, 2013, p. 40, destaques do autor). 
Primeiramente, apresentaremos uma leitura do CLG acerca do objeto da Linguística, bem como o esquema apresentado para ilustrar a natureza do signo linguístico, considerando a importância histórica dessa problemática para a constituição da Linguística enquanto ciência. Num segundo momento, olharemos para o manuscrito saussuriano "Nature de l'objet en linguistique" e as formas como esse manuscrito foi editado, observando, é claro, a sua relação com o CLG.

\title{
As obras (náo) publicadas de(?) Ferdinand de Saussure
}

\begin{abstract}
Trata-se de um texto bem estranho, que suscita o embaraço de todos aqueles que se preocupam com a exatidão e a autenticidade de um pensamento (NORMAND, 2009, p. 20).
\end{abstract}

Como sabemos, o CLG - obra sobre a qual se edificou, diretamente ou não, toda a Linguística moderna (BENVENISTE, 1989) - é uma obra póstuma organizada por Albert Sechehaye e Charles Bally, com a colaboração de Albert Riedlinger, a partir de três cursos ministrados por Ferdinand de Saussure na Universidade de Genebra, na Suíça, ao longo de três anos (1906-1907; 1908-1909; 1910-1911). Bouquet (2005) ressalta que, na verdade, "Saussure n'a d'ailleurs pas professé un cours de linguistique générale, mais trois séries de leçons sous cet intitulé, données à l'université de Genève en 1907, 1908-1909 et 1910-1911, devant un auditoire très réduit d'étudiants"'.

Após a morte de Saussure, em 1913, Albert Sechehaye e Charles Bally tomaram a iniciativa de organizar uma publicação com os ensinamentos de Saussure. Entretanto, o que o mestre genebrino havia deixado sobre os cursos eram apenas algumas notas manuscritas esparsas, que, segundo Bally e Sechehaye, eram insuficientes para a publicação de um livro. Além disso, os idealizadores do projeto não haviam assistido integralmente aos cursos ministrados pelo mestre, e todo o material de que eles dispunham para a organizaçáo eram notas manuscritas de outros alunos que haviam assistido essas conferências e que, na sua maior parte, não eram linguistas. Nesse sentido, os editores afirmam que: "pour chaque cours, et pour chaque détail du cours, il fallait, en comparant toutes les versions, arriver jusqu’à

\footnotetext{
1 "Saussure não ministrou um curso de linguística geral, mas três séries de aulas sob este título, dadas na Universidade de Genebra em 1907, 1908-1909 e1910-1911, em um auditório muito reduzido de estudantes" [traduçấo sob nossa responsabilidade].
} 
la pensée dont nous n'avions que des échos, parfois discordants"2 (BALLY; SECHEHAYE, 1916, p. 8). Considerando essas e outras dificuldades, o objetivo dos editores era: "tenter une reconstitution, une synthèse, sur la base du troisième cours, en utilisant tous les matériaux dont nous disposions, $\mathrm{y}$ compris les notes personnelles de F. de Saussure. Il s'agissait donc d'une recréation"3 (BALLY; SECHEHAY, 1916, p. 9). A primeira edição do CLG foi publicada pelas editoras francesas Payot e Rivages em 1916.

Posteriormente, o CLG sofreu duras críticas desencadeadas após Robert Godel publicar, a partir de 1941, em números sucessivos dos Cahiers Ferdinand de Saussure, outras fontes do CLG que não foram consultadas pelos editores, além de anotaçóes inéditas de Saussure que começaram a ser divulgadas nos Cahiers a partir de 1954. Em 1957, Robert Godel publica o livro Les sources manuscrites du Cours de linguistique générale, que confrontava o CLG com as anotaçóes dos alunos, mostrando que as fontes consultadas pelos editores e a forma de reconstruçáo dos cursos ministrados não se correspondiam entre si, e o CLG não correspondia a nenhuma delas. Bouquet e Engler (2002) questionam o rótulo "fontes" atribuído por Godel ao corpus recenseado se uma grande parte desses documentos não serviu de fonte para a elaboração do texto editado por Bally e Sechehaye.

Na década de 1990, mais precisamente em 1996, oito décadas após a publicação do CLG, foram encontradas notas preparatórias inéditas referente ao curso ministrado por Saussure na "orangerie" da residência da família em Genebra, entre outros documentos, e também um livro ainda não concluído, "De la double essence du langage"4. Esses manuscritos foram editados e organizados por Simon Bouquet e Rudolf Engler e publicados sob o título Écrits de Linguistique Générale ${ }^{5}$, em 2002, pela editora

2 "[...] para cada curso, e para cada pormenor do curso, comparando todas as versốes, chegar até o pensamento do qual tínhamos apenas ecos, por vezes discordantes" [tradução sob nossa responsabilidade].

3 “[...] tentar uma reconstituiçấo, uma síntese, com base no terceiro curso, utilizando todos os materiais de que dispúnhamos, inclusive as notas pessoais de F. de Saussure. Tratava-se, pois, de uma recriação" [tradução sob nossa responsabilidade].

${ }^{4} \mathrm{Na}$ verdade, trata-se de um texto que "continua a ser, como dizer isso?, um rascunho, desde que se retire do termo rascunho toda e qualquer conotação pejorativa" (ARRIVÉ, 2010, p. 45). Esses documentos foram encontrados também em 1996 e agrupados por Bouquet e Engler "sob o título de 'Da essência dupla linguagem', eles provêm, em sua grande maioria de um grande envelope que contém maços de folhas da mesma natureza e do mesmo formato, sendo que várias delas trazem a menção: 'Da dupla essência da linguagem', 'Dupla essência' ou 'Essência dupla (da linguagem)'”.

5 SAUSSURE, Ferdinand de. Escritos de Linguística Geral. Organizados e editados por Simon Bouquet e Rudolf Engler. São Paulo: Cultrix, 2012. 
francesa Gallimard. Os manuscritos originais editados na referente edição encontram-se na Bibliothèque de Genève sob o cote "Arch. de Saussure 372".

Segundo os editores, estima-se que "De la double essence du langage" seja anterior ao Cours ministrado em Genebra, pois há referências, em correspondências trocadas, de notas redigidas para um projeto de livro que Saussure estava a escrever por volta de 1891 e 1894. Além disso, em 1911, em uma conversa particular de Saussure com L. Gautier, um dos alunos de seu último curso, o mestre genebrino havia feito menção a um projeto de livro que estava escrevendo cujas anotaçóes encontravam-se perdidas em pilhas. Nesse sentido, os editores de Écrits consideram que:

[...] entre ce projet $(1891,1894)$ et l'aveu de l'existence des 'notes perdues dans des monceaux' (1911), Saussure semble bel et bien avoir rédigé, à côté des textes fragmentaires connus jusqu'à ce jour, les esquisses consistantes d'un livre sur la linguistique générale. C'est ce qui apparaît aujourd'hui, à la lecture de l'ensemble des manuscrits découverts en 1996 dans l'orangerie de l'hôtel genevois de la famille de Saussure, déposés à la Bibliothèque publique et universitaire de Genève et publiés dans le présent volume ${ }^{6}$ (BOUQUET; ENGLER, 2002, p. 12).

Assim como o CLG, a obra Écrits de linguistique générale não foi publicada por Saussure. Trata-se de uma edição de notas inacabadas, repletas de rasuras, sobre reflexốes inconclusas do mestre genebrino. Diferentemente do CLG, não se trata de uma reconstrução. Os editores apontam que "le texte établi respect au plus près le texte du manuscrit, qui demeure celui d'un brouillon, non d'un livre achevé"7 (BOUQUET; ENGLER, 2002, p. 14). Nesse sentido, os editores dos manuscritos não tiveram a pretensão de preencher as lacunas, de estabelecer relações entre uma nota e outra ou de dar um efeito de fechamento e linearidade ao texto. Segundo os editores, para intervir o menos possível sobre as notas do mestre genebrino, foram adotados alguns princípios editoriais em relação às lacunas, às ambiguidades e aos riscados, por exemplo. Desse modo, os autores apontam que "les lacunes dans le manuscrit sont transcrites par des crochets vides. Les lectures incertaines sont incluses dans des crochets. [...] Les passages biffés dans le

\footnotetext{
6 "Entre este projeto $(1891,1894)$ e a admissão da existência de 'notas perdidas em pilhas' (1911), Saussure parece, muito bem, ter redigido, ao lado dos textos fragmentários conhecidos até então, os esboços consistentes de um livro sobre a linguística geral. É o que se evidencia, hoje, com a leitura do conjunto de manuscritos descobertos em 1996 na 'orangerie' da casa genebrina da família de Saussure, depositados na Biblioteca pública e universitária de Genebra e publicados no presente volume." [traduçáo sob nossa responsabilidade].

7 "[...] o texto organizado respeita, ao máximo possível, o texto do manuscrito, que continua sendo o de um rascunho e não o de um livro acabado". [tradução sob nossa responsabilidade].
} 
manuscrit ne sont pas reproduits"8 (BOUQUET; ENGLER, 2002, p. 14).

Quanto a esse último aspecto, Silveira (2007) desenvolveu um estudo acerca das rasuras nos manuscritos saussurianos, mais especificamente, as rasuras nos manuscritos referentes à Primeira Conferência na Universidade de Genebra (1891), editado e publicado nos Écrits. Em relação à omissão das rasuras na edição dos manuscritos, a autora faz uma crítica à edição de Bouquet e Engler, afirmando que:

[...] ganhamos em compreensão com esse trabalho, mas, em comparação com a leitura dos manuscritos, resta a sensaçáo de que houve uma edição por parte de Bouquet e Engler e náo um estabelecimento do texto. No sentido mesmo em que o termo 'ediçáa' se aproxima do trabalho feito por Bally e Sechehaye (SILVEIRA, 2007, p. 13, destaques do autor).

Sofia (2012), por seu lado, aponta uma série de intervenções dos editores sobre os manuscritos que o levam a concluir que se trata de "une édition, nécessairement fondée, en tant que telle, non moins que celle effectuée il y a bientôt cent ans par Bally et Sechehaye, sur des critèries éditoriaux précis" (SOFIA, 2012, p. 6). O autor realiza um estudo minucioso do trabalho de edição dos manuscritos saussurianos publicados pela editora francesa Gallimard. Dentre os vários aspectos apontados por Sofia (2012), em que há intervençóes operadas pelos editores sobre o manuscrito, o autor destaca:

\begin{abstract}
[...] l'omission des passages biffés, annoncée dès la préface, est opérée de manière irrégulière. Il existe par example des termes ou des phrases qui, ayant été biffés par Saussure, sont reproduits dans l'édition Gallimard (cf. " anéantissement ", AdeS 372, p. 137 [ELG, 67c]). En certains points, les éditeurs aussi ont omis des passages qui n’avaient pas été biffés par Saussure, mais seulement dépréciés. Tel est le cas, par exemple, d'un fragment figurant en haut de la page 100, que Saussure, sans le biffer, qualifie dans la marge de " mauvais " : " ...il est exactement de même d'un mot, dont la première existence est d'être un " morceau d'étoffe " ou une figure vocale; $Z^{\circ}$ et la seconde [ ]» (AdeS 372, p. 100 [ELG, p. 54]) $)^{10}$ (SOFIA, 2012, p. 5-6).
\end{abstract}

8 "[...] as lacunas no manuscrito são transcritas por espaços vazios entre colchetes. As leituras incertas são incluídas entre colchetes. [...] As passagens barradas no manuscrito não foram reproduzidas" [tradução sob nossa responsabilidade].

9 "[...] uma ediçáo, necessariamente fundada, enquanto tal, não menos que aquela efetuada há quase cem anos por Bally e Sechehaye, sob critérios editoriais precisos” [tradução sob nossa responsabilidade].

10 "A omissão das passagens barradas, anunciada desde o prefácio, é operada de maneira irregular. Existe, por exemplo, termos ou frases que, tendo sido barradas por Saussure, são reproduzidas na edição Gallimard (cf. " anéantissement ", AdeS 372, p. 137 [ELG, 67c]). 
Considerando o apontamento dos autores sobre o processo de edição dos manuscritos, é preciso ter em vista que se trata de um trabalho filológico e de exegese estabelecido a partir de critérios definidos pelo pesquisador. Nesse sentido, o trabalho de edição dos textos saussurianos não é alheio ao gesto interpretativo do sujeito pesquisador. A apreensão desse material pelo processo de edição constitui-se sobre uma representação e não uma reprodução tal como ele é. Os originais e a edição desses mesmos constituemse materialidades distintas que não se sobrepóem. Os manuscritos sáo, antes de tudo, um rascunho, e, enquanto tal, apresentam as marcas de um processo de elaboração da produção do conhecimento sobre a língua, como, por exemplo, as rasuras, os barrados e os acréscimos às margens do texto. Essas marcas não fazem parte do texto final, compóem parte de rascunhos que antecedem o texto final, as quais remetem às hesitaçóes do autor sobre sua própria reflexão. A publicação da edição dos manuscritos não é propriamente uma "obra final", uma vez que foi publicada sem que seu autor pudesse tê-la concluído.

Desse modo, uma outra edição desses documentos foi proposta pelo linguista suíço René Amacker e publicada sob o título Sciences du langage - De la double essence du langage, Édition des Écrits de linguistique générale établie par René Amacker, em 2011, pela editora suíça Librarie Droz S.A. No prefácio dessa edição, Amacker relata como tomou conhecimento de tais manuscritos encontrados em 1996. Segundo o autor, Vincent Barras, Olivier Flournoy e Sonu Shamdasani foram as pessoas que receberam esse material da viúva de Raymond de Saussure, filho de Ferdinand de Saussure: estavam guardados em uma "orangerie" do hotel da família de Saussure em Genebra, onde a viúva de Raymond morava. Tais documentos foram encaminhados para o departamento de manuscritos da Bibliothèque Publique et Universitaire, hoje designada Bibliothèque de Genève, aos cuidados de Phillippe Monnier. Algum tempo depois, Amacker procurou Monnier para falar de sua preocupação em ver os manuscritos saussurianos classificados por um especialista e, entáo, recomendou à Monnier que procurasse Rudolf Engler para cuidar da catalogação e classificação de tais documentos. E assim foi feito. Segundo Amacker, Engler desejava publicar uma edição crítica em duas colunas, uma com a imagem aproximativa da disposição do manuscrito, e outra com o texto no estado em que Saussure

Em alguns pontos, os editores também omitiram passagens que não tinham sido barradas por Saussure, mas somente depreciadas. É o caso, por exemplo, de um fragmento figurando no alto da página 100, que Saussure, sem o barrar, qualifica na margem de "ruim": “... é exatamente o mesmo de uma palavra, cuja primeira existência é de ser um 'pedaço de pano' out uma figura vocal; $Z^{\circ}$ e a segunda [...] (AdeS 372, p. 100 [ELG, p. 54]). 
havia deixado. Por razóes desconhecidas, a publicação da editora francesa Gallimard náo é uma edição crítica. Em respeito ao desejo do amigo a quem dedica sua obra no prefácio, Amacker justifica a publicação de sua edição crítica, endereçada a um público especializado, como uma forma de homenagear seu colega e amigo prematuramente falecido.

Nessa edição, René Amacker faz uma crítica à edição proposta pela Editora Gallimard e, inclusive, apresenta um quadro comparativo entre as duas ediçóes para apontar as faltas e os equívocos da referida edição francesa. Em relação ao título Écrits de linguistique générale, Amacker, assim como Ludwig Jäger, aponta uma problemática vizinhança desse título com aquele do CLG, com as notas manuscritas pessoais de Saussure e a redação contínua dos cursos universitários. De fato, a designação "Linguística geral", como apontam os editores da edição francesa, constitui-se de:

[...] trois corpus de textes: $1^{\circ}$ des écrits de Ferdinand de Saussure ; $2^{\circ}$ des notes prises par ses étudiants lors de trois séries de cours professés à Genève entre 1907 et 1911 ; 30 le livre rédigé après sa mort par Charles Bally e Albert Sechehaye et publié en 1916 sous le titre Cours de Linguistique Générale, principalement sur la base de ces notes d'étudiants ${ }^{11}$ (BOUQUET; ENGLER, 2002, p. 7).

No caso específico da obra em questão, os editores justificam o título atribuído, Écrits de Linguistique Générale, como uma retomada do "nome administrativo dos cursos genebrinos", pois:

[...] le livre de 1916 ayant attaché l'étiquette de linguistique générale à la pensée saussurienne, on l'a conservée dans le titre de la présente édition comme propre, non à référer aux multiples emplois de cette expression lors du précédent tournant de siècle, mais à désigner un ensemble de réflexions spécifique au sein de la production intellectuelle du linguiste de Genève ${ }^{12}$ (BOUQUET; ENGLER, 2002, p. 8).

\footnotetext{
11 "[...] três corpus de textos: $1^{\circ}$ os escritos de Ferdinand de Saussure; $2^{\circ}$ as notas de seus alunos, por ocasiâo de três séries de cursos ministrados em Genebra, entre 1907 e 1911; 30 o livro escrito, depois de sua morte, por Charles Bally e Albert Sechehaye e publicado em 1916 com o título Cours de linguistique générale e baseado, principalmente, nessas notas de estudantes" [tradução sob nossa responsabilidade].

12 "[...] o livro de 1916 tendo sido etiquetado de linguística geral ao pensamento saussuriano, nós conservamos no título da presente edição [...] por ser apropriado, não por referência aos múltiplos empregos dessa expressão na virada do século, mas para designar um conjunto de reflexôes específico no seio da produção intelectual do linguista de Genebra” [tradução sob nossa responsabilidade].
} 
A crítica de Amaker a esse título é que essa publicação não só contempla as notas preparatórias para o CLG, mas também notas anteriores ao CLG, como por exemplo, notas de conferências, notas preparatórias para um livro, entre outros. Além disso, na época em que Saussure ministra o CLG, a designação "Linguística geral" remete a objetos distintos, como bem sabem os editores dos Écrits e apontam essa problemática no prefácio da obra.

Uma segunda crítica que Amacker faz à edição francesa é que as notas encontradas em 1996 e publicadas sob o título "De la double essence du langage", na verdade, não se trata de manuscritos de um livro sobre Linguística geral, como é apontado no prefácio da obra Écrits de linguistique générale. Segundo Amacker, trata-se de uma parte importante das notas de Saussure as quais ele mesmo havia reunido em uma embalagem sobre a qual ele escreveu "Science du langage", justificando, também, desse modo, o título da ediçáo crítica proposta por Amacker.

A partir dessas diferentes ediçôes, considerando também o CLG, obra que desencadeou todas essas discussôes, dedicamo-nos a compreender como a reflexão sobre o objeto da Linguística é constituída a partir do Cours, nas duas ediçốes publicadas dos manuscritos encontrados em 1996, bem como o manuscrito saussuriano "Nature de l'objet en linguistique".

Além disso, é preciso ter em vista que o manuscrito que selecionamos para desenvolver nossa reflexão, intitulado "Nature de l'objet en linguistique", está situado entre os manuscritos de "De la double essence du langage", os quais não serviram de fonte para a elaboração do CLG. Desse modo, a nossa proposta é desenvolver uma reflexão sobre o objeto da Linguística tal como foi proposta no CLG, bem como as críticas atribuídas a essa problemática, e, a seguir, considerar também o manuscrito "Nature de l'objet en linguistique" na sua relação com as ediçôes publicadas de "De la double essence du langage".

\section{À procura do objeto perfeito: a Linguística torna-se ciência}

Bien loin que l'objet précède le point de vue, on dirait que c'est le point de vue qui crée l'objet

(SAUSSURE, 1995, p. 23).

O questionamento saussuriano - "Qual é o objeto, ao mesmo tempo integral e concreto, da Linguística? -, coloca no centro das discussôes 
algo que, até entáo, não era exatamente um problema para os linguistas. Segundo Normand (2009, p. 35), "na época em que Saussure leciona a Linguística geral, a evidência para os linguistas é de que eles se ocupam com a linguagem e com as linguas; assim o afirmam, sem estabelecer uma relação clara entre esses dois termos [...]”. Além disso, segundo a autora, alguns linguistas sustentavam que tudo na linguagem é histórico, enquanto outros defendiam que tudo é social. Saussure, por seu lado, desafia a dificuldade desse questionamento ao "levar seus contemporâneos a se colocar a questáo que, precisamente, eles evitavam: vocês sabem o que fazem e do que falam?" (NORMAND, 2009, p. 37). Naturalmente, a questão inicial proposta sobre o objeto da Linguística não era fácil de ser respondida, pois o objeto da Linguística não se assemelha ao objeto de outras ciências. Desse modo, o linguista genebrino contextualiza a dificuldade de delimitar qual é o objeto da Linguística, considerando a definição do objeto de outras ciências:

D'autres sciences opèrent sur des objets donnés d'avance et qu'on peut considérer ensuite à différents points de vue ; dans notre domaine, rien de semblable. Quelqu'un prononce le mot français nu : un observateur superficiel sera tenté d'y voir un objet linguistique concret ; mais un examen plus attentif y fera trouver successivement trois ou quatre choses parfaitement différentes, selon la manière dont on le considère : comme son, comme expression d'une idée, comme correspondant du latin nudum, etc. Bien loin que l'objet précède le point de vue, on dirait que c'est le point de vue qui crée l'objet, et d'ailleurs rien ne nous dit d'avance que l'une de ces manières de considérer le fait en question soit antérieure ou superière aux autres $^{13}$ (SAUSSURE, 1995, p. 23).

No exemplo proposto pelo mestre genebrino, a palavra "nu", são ressaltadas as possibilidades de ver aí diferentes instâncias, como, por exemplo, um objeto linguístico concreto, um som, uma expressão de uma ideia, um correspondente do latim "nudum". A partir dessa problemática sobre o objeto linguístico e as várias abordagens possíveis, o aforismo saussuriano "é o ponto de vista que cria o objeto" está no cerne daquilo que ficou conhecido como o corte epistemológico promovido pelo mestre

13 "Outras ciências trabalham com objetos dados previamente e que se podem considerar, em seguida, de vários pontos de vista; em nosso campo, nada de semelhante. Alguém pronuncia a palavra francesa $n u$ : um observador superficial será tentado a ver nela um objeto linguístico concreto; um exame mais atento, porém, nos levará a encontrar no caso, uma após outra, três ou quatro coisas diferentes, conforme a maneira pela qual consideramos a palavra: como som, como expressão de uma ideia, como correspondente do latim nudum etc. Bem longe de dizer que o objeto precede o ponto de vista, diríamos que o ponto de vista que cria o objeto; aliás, nada nos diz de antemáo que uma dessas maneiras de considerar o fato em questão seja anterior ou superior às outras" [traduçấo sob nossa responsabilidade]. 
genebrino na história da Linguística. Segundo Normand (2009, p. 38):

Saussure não inventa a questão do objeto nem a dos critérios de escolhas que lhe é associada; ela está ligada, nessa época, à reflexão positivista sobre as ciências e sabe-se que essa reflexão constitui em A. Comte a preparação de toda reflexáo científica, quer se trate da sociologia - 'ciência que tem por objeto próprio o estatuto de fenômenos sociais' -, quer ser se trate da biologia.

Uma vez definido o objeto da Linguística, é preciso considerar de que natureza é esse objeto. Antes de tudo, Saussure esclarece que a língua não é uma nomenclatura, onde os nomes estariam associados às coisas. Para reforçar a simplicidade de uma concepção de língua enquanto nomenclatura, é introduzido o seguinte desenho (Figura 1):

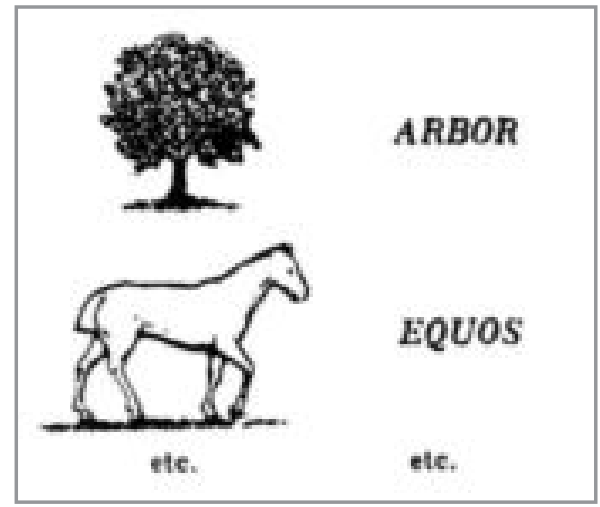

Figura 1: Exemplo ilustrativo de concepçáo de língua enquanto nomenclatura Fonte: Saussure (1995, p. 97).

Segundo a leitura de Saussure, essa concepção de língua mostra-se falha e limitada sobre vários aspectos e não permite depreender se a palavra é de natureza mental ou psíquica, por exemplo. Esse esquema mostra apenas que a relação entre as palavras e as coisas é uma operação muito simples, o que, segundo Saussure, está bem longe da verdade. Desse modo, em oposição a essa concepçáo de língua enquanto nomenclatura, Saussure propóe uma concepçáo de língua imanente, definindo-a por si mesma, independente de todo objeto que lhe seja exterior. Nessa perspectiva, a língua é definida enquanto um sistema de signos. Esses signos, por sua vez, unem "non une chose et un nom, mais un concept et une image acoustique"14 (SAUSSURE,

14 "[...] não uma coisa e uma palavra, mas um conceito e uma imagem acústica" [tradução sob 
1995, p. 98). Para exemplificar a concepção de signo linguístico, é então proposto o seguinte esquema (Figura 2):

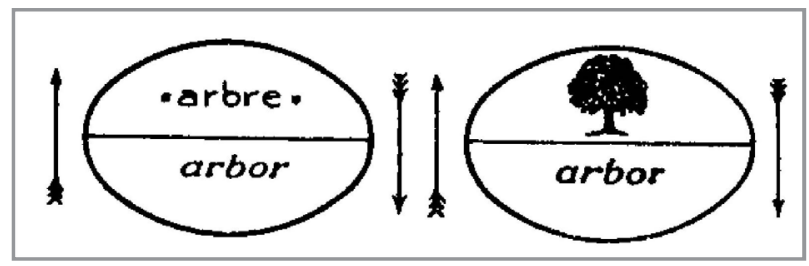

Figura 2: Exemplo ilustrativo de signo linguístico

Fonte: Saussure (1995, p. 99.).

O principal argumento de Saussure para refutar uma concepção de língua enquanto nomenclatura é a comparação entre línguas, como sugere a primeira representação do signo linguístico - "arbre"/arbor. Não se trata de considerar a relação entre a língua e o mundo, mas a relação entre as línguas. A concepçáo de língua imanente proposta pressupóe que a arbitrariedade do signo não está associada ao objeto referente, mas constitui-se entre o significado e o significante, considerando a existência de línguas diferentes.

O fato de existir línguas e não apenas uma língua é posto em discussão por Saussure ao questionar o arbitrário do signo, pois esse questionamento reporta à relação entre as línguas e não entre as línguas e o mundo. Como ressalta Sériot (2015, p. 57), "há entre nós e as coisas um intermediário, um médium: a linguagem, logo a imperfeição e a fi nitude se manifestam no fato mesmo da multiplicidade de línguas". A multiplicidade das línguas remete também à explicação bíblica para a origem das línguas narrada no mito de Babel, no qual tal questấo constitui-se como um castigo divino para punir os homens com o desentendimento. Teria havido um tempo em que "o mundo inteiro falava a mesma língua, com as mesmas palavras". Entretanto, não sabemos que língua era essa, nem em que língua Deus criou o mundo, ao enunciar "Faça-se a luz", nem em que língua Adão falava com Eva, por exemplo. Segundo a narração bíblica, Adão já foi concebido dotado de uma língua na qual designou, pela primeira vez, os objetos ainda não designados. O mito de Babel divide a história da(s) língua(s) em um antes e um depois, entre um antes onde existia apenas uma língua e todos se entendiam, e um depois marcado pela multiplicidade das línguas e pelo desentendimento. Nesse sentido, segundo Sériot (2015, p. 57), "a multiplicidade de línguas que é a punição divina, logo a desunião, a separação, enquanto o estado pré-

nossa responsabilidade]. 
babélico é descrito por contraste como o éden da comunicação no seio de uma língua única, da fusão e da comunicação sem obstáculo".

O questionamento de Saussure, evidentemente, não visa à origem das línguas ${ }^{15}$, mas reporta ao "porquê" de haver línguas e procura desenvolver essa reflexão a partir da definição de língua e da compreensão do sistema que rege seu funcionamento. $\mathrm{O}$ autor ampara-se na arbitrariedade da relação entre significado e significante para compreender a constituição do sistema linguístico. Desse modo, com base em um paradigma positivista de ciência, o mito de Babel não é mencionado pelo mestre genebrino, mas ressoa em surdina, significando sob a forma do não-dito. Como bem destaca Gadet e Pêcheux (2010, p. 19),

[...] se o objeto da linguística consiste no duplo fato de que existe língua e de que existem línguas, é necessário pensar no momento de sua divisão que, aliás, é a imagem de Babel: o mito apresenta a divisẫo das línguas coincidindo com o começo do Estado, do direito, das ciências e do prazer sexual... logo, com o começo de um impossível retorno ao paraíso perdido contemporâneo mesmo dessa perda.

Para Saussure, que não se interessa pela origem das línguas, o falante não é um Adão bíblico que existe antes da linguagem ou que poderia criá-la ou mudá-la voluntariamente. Para o autor, a língua é social e só existe no seio de uma comunidade falante. Uma vez definido o objeto da Linguística, que é a língua, o sujeito não está incluído no corte epistemológico promovido pelo mestre, de modo que o sujeito náo é a origem da língua e pouco importa a origem $\mathrm{da}(\mathrm{s})$ língua(s).

Uma das críticas ao CLG é que esse exemplo ilustrativo (figura 2), especialmente o segundo balão, que representa o signo linguístico, estaria em contradição em relação à concepção de língua enquanto nomenclatura - que

\footnotetext{
${ }^{15}$ A problemática sobre a origem das línguas no domínio da ciência é bastante delicada. Segundo Auroux (2008), "em 1866, as pesquisas sobre a origem das linguas foram objeto de proibição pela Societé de Linguistique de Paris” (p. 11). Trata-se de uma impossibilidade científica cujas pesquisas são baseadas apenas em hipóteses e nenhuma descoberta ou dado concreto. Entretanto, mais contemporaneamente, a origem das línguas voltou a ser tema de pesquisa, o que, segundo Auroux (2008, p. 13), "mostra claramente que a posição da Societé linguistique não foi táo unânime na comunidade". Para Gadet e Pêcheux (2010, p. 21), "as finalidades últimas da linguística, longe de visar a uma soluçấo teórica, parecem manter uma relação estreita com o desejo político de terminar de uma vez por todas com os obstáculos que entravam a 'comunicação' entre os homens. Do esperanto às línguas lógicas, os linguistas não param de procurar a nova língua universal capaz de reproduzir o milagre de uma Pentecostes científica: Babel reencontrada”. A complexidade do estudo da origem das línguas se deve, sobretudo, por ser uma problemática que, de uma maneira ou de outra, envereda para questáo religiosa e mitológica, distanciando-se, desse modo, de uma questão teórica e científica.
} 
é criticada - e assemelha-se ao primeiro desenho apresentado para questionar a simplicidade de uma concepçáo de língua enquanto nomenclatura. A segunda representação de signo apresenta o desenho de uma árvore, o que parece remeter ao objeto concreto "árvore". Segundo Gadet (1996, p. 3536),

[...] cette représentation est fort maladroite, car elle laisse entendre que d'une part (côté signifié) il existe une zone de réel délimitée à quoi va être attribué le signifiant arbor, et d'autre part (côté signifiant) qu'il existe un signifiant que l'on va attribuer au signifié. Ce serait revenir, à travers un détour, à la nomenclature ${ }^{16}$.

Sobre esse aspecto, é preciso determo-nos um pouco mais.

A imagem e a sua respectiva designação parece ser uma evidência de algo muito simplório, o qual poderia também remeter ao processo de aprendizagem da escrita pelas crianças. Entretanto, como Saint-Exupéry, na sua célebre obra Le Petit Prince (O Pequeno Príncipe), já tentava nos avisar, mesmo a representação através do desenho pelas crianças pode estar sujeita ao ponto de vista. Na referida obra, o narrador conta sua experiência aos seis anos de idade, quando, ao mostrar o desenho de uma jiboia digerindo um elefante, os adultos náo conseguiam ver uma jiboia e muito menos um elefante, e, para seu desapontamento, os adultos só conseguiam ver, naquele desenho, a representação de um chapéu.

$\mathrm{O}$ que poderia ser mais incômodo para uma criança questionar a evidência de uma representação, sobretudo quando o desenho é acompanhado de sua respectiva designaçáo? Esse questionamento remetenos à provocação de Magritte em sua obra La trahison des images, composta por um desenho de um cachimbo e pelo enunciado "ceci n'est pas une pipe" (Isto náo é um cachimbo). Essa obra, que parece desacomodar algumas evidências, poderia ser entendida também como uma contestação de uma concepçáo de língua enquanto nomenclatura, ao colocar em questionamento a evidência daquilo que parece não poder ser outra coisa senão um cachimbo. Uma espécie de provocação a uma forma simplória de definir a língua, colocando etiquetas com nomes sobre os objetos. $\mathrm{O}$ artista parece voltar-se para o observador e dizer: "Está vendo esse desenho cujas formas parecem remeter a um cachimbo? Então, esse desenho não é um 16 "[...] esta representaçáo é muito avessa, porque ela deixa entender que, de uma parte (o lado do significado) existe uma zona do real delimitada a que vai ser atribuído o significante arbor, e outra parte (o lado do significante) que existe um significante que vai se atribuir ao significado. O que seria retornar, através de um desvio, à nomenclatura" [tradução sob nossa responsabilidade]. 
cachimbo!". Entretanto, ao desacomodar essa evidência e afirmar o que o desenho náo é, o artista deixa para o observador refletir sobre o que então poderia ser aquele conjunto de formas que parece remeter a um cachimbo.

Considerando a crítica em relação ao esquema do signo linguístico proposto no CLG, que associa um desenho a um nome e remete à concepção de língua enquanto nomenclatura que é criticada, na tentativa de "corrigir" a dita representação, poderíamos dizer (Figura 3), assim como Magritte, que ceci n'est pas un arbre:

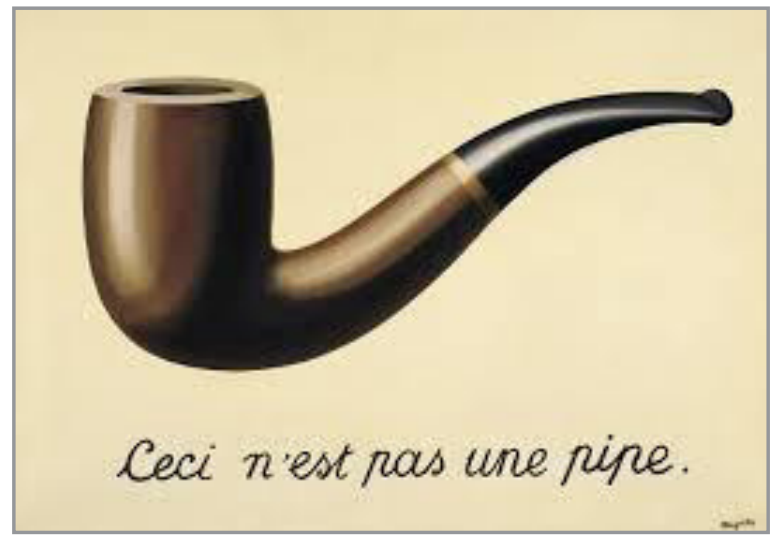

Figura 3: La trahison des images - René Magritte Fonte: https://en.wikipedia.org/wiki/The_Treachery_of_Images

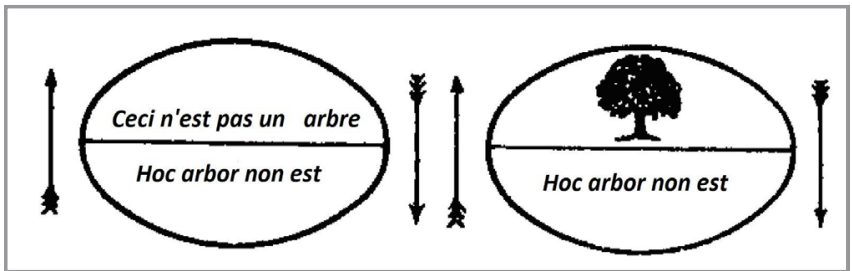

Figura 4: Ceci n'est pas un arbre

Fonte: nossa.

Entretanto, o enunciado que nega aquilo que não poderia ser outra coisa senão uma árvore coloca ainda mais questionamentos. A obra de Magritte parece ir além da recusa de uma concepção de língua enquanto nomenclatura. $\mathrm{Na}$ obra do artista surrealista, o enunciado parece negar a evidência da imagem daquilo que poderia facilmente ser reconhecido como um cachimbo. Como aquilo poderia não ser um cachimbo se o conjunto de 
traços parece formar exatamente um cachimbo? Esse enunciado provocativo proposto por Magritte permite-nos avançar um pouco mais em relaçáo à natureza do signo linguístico.

Para nós, o enunciado "ceci n'est pas une pipe" parece colocar em causa as várias instâncias em que o cachimbo pode se apresentar. Antes de tudo, o enunciado dissocia a imagem e o referente, primeira instância de como o cachimbo pode ser apresentado. $\mathrm{O}$ enunciado, na verdade, refere-se à imagem, e esta, é claro, náo é o referente/objeto real cachimbo. Ao mesmo tempo, o enunciado chama a atenção para a imagem, segunda instância de como o cachimbo pode ser apresentado, e a sua relaçáo com o referente, ressaltando que a imagem náo poderia ser o cachimbo objeto referente. Uma outra forma como o cachimbo é apresentado na obra é pela própria palavra "cachimbo", isto é, a palavra "cachimbo", além de possuir um referente, uma imagem que o representa, possui igualmente uma existência na língua por meio do significante "cachimbo", e também um significado que remete à ideia de "cachimbo". Além disso, há ainda uma forma um pouco mais sutil de como o "cachimbo" pode ser referido na língua sem necessariamente ser pelo seu nome: o pronome demonstrativo "isto" constitui-se enquanto um recurso da língua que permite designar o referente, retomando-o sem mencionar o nome. "Isto", diferentemente do signo linguístico "cachimbo", não possui um referente, "isto" constitui-se como uma forma vazia que só tem existência na língua. Desse modo, em relaçáo ao "cachimbo", tem-se: o referente, a imagem, a palavra escrita, a imagem acústica $\left[\mathrm{ka} \cdot \int^{\prime} \text { i.bo }\right]^{17}$, a ideia de cachimbo, a designaçáo "isto" que remete a cachimbo. Trata-se de instâncias diferentes que apresentam o cachimbo sob diferentes perspectivas, de forma que produz um desdobramento que permite apreender um dado objeto sob diferentes pontos de vista.

Retomando o exemplo do signo linguístico proposto no CLG, esse exemplo parece apenas dar conta de signos que possuem um referente material. Entretanto, como poderíamos, por exemplo, ilustrar o signo linguístico "isto" (ceci/hoc) do enunciado "isto não é um cachimbo" (ceci n'est pas une pipe/hoc arbor non est)? A forma linguística "isto" não possui um referente nem poderia ser representado por uma imagem, no entanto, "isto" possui uma existência real na língua. Curiosamente, sobre a natureza dos pronomes, Benveniste (2005, p. 277) aponta que:

${ }_{17}$ Ashby, S. et al. (2012). A Rule Based Pronunciation Generator and Regional Accent Databank for Portuguese. Proceedings of Interspeech 2012. Disponível em: <http://www. portaldalinguaportuguesa.org $/ \% 3 \mathrm{E}$ ?action=fonetica\&region=spx\&act=details\&id $=5553>$. Acesso em: set. 2015. 
[...] todas as línguas possuem pronomes e, em todas, eles se definem como referindo-se às mesmas categorias de expressão (pronomes pessoais, demonstrativos, etc.) A universalidade dessas formas e dessas noçóes faz pensar que o problema dos pronomes é ao mesmo tempo um problema de linguagem e um problema de línguas, ou melhor, que só um problema de línguas por ser, em primeiro lugar, um problema de linguagem.

A natureza dos pronomes parece referendar o princípio do arbitrário do signo, uma vez que se trata de formas linguísticas que são comuns a todas as línguas, mas que não têm um referente material que possa representá-las tal como o exemplo da "árvore". A singularidade dos pronomes é que, ainda que não tenham um referente material específico, podem estar associados a referentes diferentes a cada instância de enunciação.

$\mathrm{O}$ signo linguístico saussuriano não considera o referente, pois nem todos os signos possuem um referente material, tal como o exemplo da "árvore". A língua constitui-se também de elementos que só têm existência na língua, como os pronomes, as preposiçôes, os artigos, por exemplo, os quais não poderiam ser representados por uma concepção de língua enquanto nomenclatura. É a partir desse pressuposto que Saussure propóe uma concepção de língua imanente, a qual pode ser definida por si mesma sem relação com aquilo que lhe é exterior.

Desse modo, se partimos do pressuposto de que só o referente poderia receber a designação "árvore", e que a sua representação pelo desenho não contempla a sua totalidade, estamos agindo tal como os cartógrafos do conto do escritor argentino Jorge Luis Borges, referido por Sériot (2000). No conto de Borges, Do rigor da ciência ${ }^{18}$, os cartógrafos buscam um mapa perfeito do império que o represente na sua totalidade. Na busca do mapa perfeito, os cartógrafos decidem criar um mapa em escala $1: 1$, onde $1 \mathrm{~cm}$ no mapa representa $1 \mathrm{~cm}$ do território. Nesse sentido, não se trata mais de uma representação nem de um mapa, trata-se de uma reduplicação do território. Segundo Sériot (2015, p. 56),

A aporia que nos descreve Borges é a incapacidade dos esforços de

\footnotetext{
${ }^{18}$ Naquele Império, a Arte da Cartografia logrou tal perfeição que o mapa de uma única Província ocupava toda uma Cidade, e o mapa do império, toda uma Provincia. Com o tempo, esses Mapas Desmedidos não satisfizeram e os Colégios de Cartógrafos levantaram um Mapa do Império, que tinha o tamanho do Império e coincidia pontualmente com ele. Menos Adictas ao Estudo da Cartografia, as Geraçôes Seguintes entenderam que esse dilatado Mapa era Inútil e não sem Impiedade o entregaram às Inclemências do Sol e dos Invernos. Nos desertos do Oeste perduram despedaçadas Ruinas do Mapa, habitadas por Animais e por Mendigos; em todo o País não há outra relíquia das Disciplinas Cartográficas. BORGES, Jorge Luis. Do rigor da ciência. In:
}

História Universal da Infâmia. Porto Alegre: Globo, 1975. 
representação total, a impossibilidade de dar conta exaustivamente do real: dizer o Todo equivale a nada dizer [...] O texto de Borges é a ilustração lúcida do que Lacan chama de "não-todo", a impossibilidade de (tudo) dizer, a dupla questão fantasmática da exaustividade e o que chamamos em linguística a transparência referencial.

A representação perfeita é então impossível sob pena de deixar de ser uma representação, visto que a representação e o conhecimento do que quer que seja estão investidos do impossível da totalidade. Retomando, mais uma vez, Sériot (2015, p. 56), "as palavras e as coisas não se recobrem totalmente, há uma incompletude de todo conhecimento, que é a condição mesma do conhecimento" 19 .

É preciso considerar ainda que o esquema apresentado no CLG não tem o objetivo de propor uma representaçáo de árvore, mas de exemplificar a relação que se estabelece entre o significante/imagem acústica e o significado/ conceito. A obra de Magritte questiona a relação entre o referente e a sua representação, mas o esquema proposto por Saussure, ainda que sujeito ao equívoco, não associa um nome e um referente, mas um significante e a ideia que esse significante remete em uma dada língua. Como não poderia deixar de ser, a máxima saussuriana "o ponto de vista cria o objeto", mais uma vez, permite-nos compreender de que ponto de vista tais autores abordam o seu objeto e que todo conhecimento repousa sob um ponto de vista e, por isso, é sempre incompleto.

\section{O objeto em Linguística nos escritos "De la double essence du langage" - les notes de l'orangerie}

Que estranho destino esse das ideias, e como parecem às vezes viver pela sua própria vida, revelando ou desmentindo ou recriando a figura de seu criador (BENVENISTE, 2005, p. 48).

Como sabemos, os escritos editados sob o título De la double essence du langage são anteriores aos cursos ministrados por Saussure em Genebra. Estima-se que essas notas tenham sido escritas na década de 1890. As principais fontes citadas como referência da existência de um livro que Saussure estaria escrevendo remontam a correspondências trocadas e

\footnotetext{
19 "[...] as palavras e as coisas não se recobrem totalmente, há uma incompletude de todo conhecimento, que é a condição mesma do conhecimento" [Tradução de Amanda Eloina Scherer e Maria Iraci Sousa Costa. In: Revista Organon, n. 59, 2015].
} 
a conversas particulares. Entretanto, tais notas só foram encontradas na década de 1990, ou seja, quase cem anos separam a escritura das referidas notas e sua descoberta.

Desse modo, o que propomos é uma reflexão, a partir do estudo comparativo, entre as duas ediçóes de De la double essence du langage e o manuscrito saussuriano "Nature de l'objet en linguistique", o qual faz parte dos manuscritos editados e publicados em De la double essence du langage. A partir da nossa análise, objetivamos compreender a complexidade da reflexão sobre o objeto da Linguística, questionamento esse de extrema importância na obra saussuriana e que contribuiu para alçar a Linguística como modelo para as ciências humanas no apogeu do movimento estruturalista. Considerando o aforismo saussuriano de que "o ponto de vista cria o objeto", diríamos que as diferentes ediçôes publicadas dos escritos também apontam pontos de vista diferentes no que toca ao processo de edição das notas.

O manuscrito intitulado "Nature de l'objet en linguistique" foi escrito em quatro páginas de um pequeno caderno do qual foram retiradas. As folhas foram numeradas de 7 a 10. Essa numeraçáo foi estabelecida por Rudolf Engler, que foi quem se ocupou da organizaçáo de tais manuscritos. Sobre a numeração das páginas, Sofia (2012) faz uma crítica a essa organizaçáo, pois há, pelo menos, quatro versões da transcrição feita por Rudolf Engler. Dessas quatro, Sofia (2012) aponta que três delas exibem uma característica surpreendente, a saber,

[...] l'ordre original des pages, et donc l'ordre même du texte, a été altéré. Et je dis bien l'ordre des pages et du texte, car, dans bien des occasions, le recto et le verso (deux pages) d'un même feuillet ont été séparés, et parfois même - quoique moins souvent-l'ordre du texte a été modifié à l'intérieur d'une même page ${ }^{20}$ (SOFIA, 2012, p. 4).

Nesse estudo, não nos deteremos na numeração das páginas atribuída por Engler, mas consideraremos as duas ediçōes propostas de De la double essence du langage, mais especificamente a nota "Nature de l'objet en linguistique", considerando a sua relaçáo com o manuscrito saussuriano editado.

\footnotetext{
20 "a ordem original das páginas, e por isso a ordem mesma do texto, foi alterada. E eu disse bem, a ordem das páginas e do texto, pois, em algumas ocasiōes, a frente e o verso (duas páginas) de uma mesma folha foram separadas, e às vezes mesmo - embora menos frequente - a ordem do texto foi modificada no interior de uma mesma página" [tradução sob nossa responsabilidade]
} 
A seguir, apresentamos um quadro comparativo entre as ediçóes publicadas e o manuscrito editado. Trata-se de quatro páginas de manuscrito $(7,8,9,10)$, onde destacamos com uma linha as partes que foram editadas. Como se trata de um manuscrito pleno de passagens barradas, algumas passagens não foram editadas pela edição francesa. Vejamos, então, o manuscrito e as respectivas ediçóes francesa e suíça (Quadro comparativo 1):

\section{Quadro comparativo 1: Manuscrito saussuriano, Écrits e Science du langage}

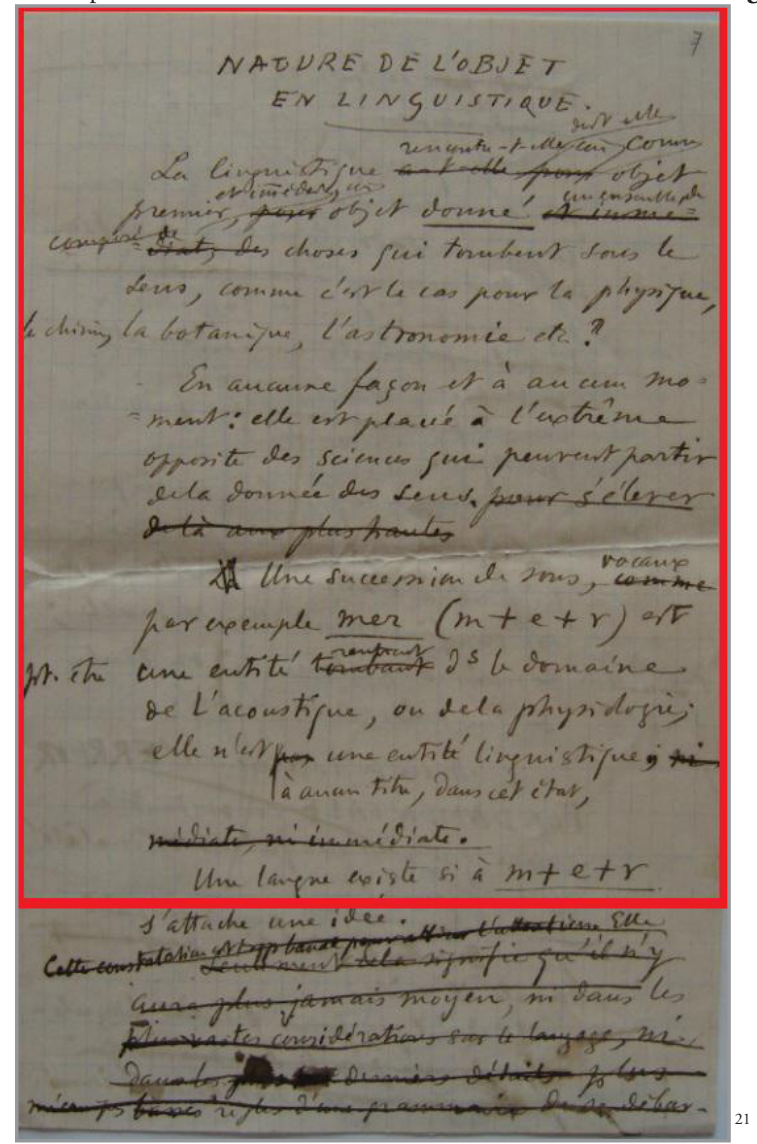

Fonte : AdeS 372, p. 7

${ }^{21}$ As cópias dos manuscritos saussurianos presentes neste artigo foram-nos doadas pela Professora Dr. Irène Fenoglio durante nosso estágio sanduíche em Paris, sob sua coorientação, junto ao Institut des Textes et Manuscrits Modernes (ITEM), na École Normale Supérieure. Agradecemos vivamente à Professora Irène Fenoglio por esse belo presente e pela sua generosidade. 


\begin{tabular}{|c|c|}
\hline $\begin{array}{c}\text { ÉCRITS DE LINGUISTIQUE } \\
\text { GÉNÉRALE } \\
\text { Texte établi et édité par Simon Bouquet et } \\
\text { Rudolf Engler }\end{array}$ & $\begin{array}{c}\text { SCIENCE DU LANGAGE } \\
\text { DE LA DOUBLE ESSENCE DU } \\
\text { LANGAGE } \\
\text { Édition des Écrits de linguistique générale } \\
\text { établie par René Amacker }\end{array}$ \\
\hline $\begin{array}{l}\text { Nature de l'objet en linguistique } \\
\text { La linguistique rencontre-t-elle devant } \\
\text { elle, comme objet premier et immédiat, } \\
\text { un objet donné, un ensemble de choses qui } \\
\text { tombent sous le sens, comme c'est le cas } \\
\text { pour la physique, la chimie, la botanique, } \\
\text { l'astronomie, etc. ? } \\
\text { En aucune façon et à aucun moment : elle } \\
\text { est placée à l'extrême opposite des sciences } \\
\text { qui peuvent partir de la donnée des sens. } \\
\text { Une sucession de sons vocaux, par exem- } \\
\text { ple mer ( } m+e+r \text { ), est peut-être une unité } \\
\text { rentrant dans le domaine de l'acoustique, } \\
\text { ou de la physiologie ; elle n'est à aucun titre, } \\
\text { dans cet état, une entité linguistique. } \\
\text { Une langue existe si à } m+e+r \text { s'attache une } \\
\text { idée. }\end{array}$ & $\begin{array}{l}\text { [2.7]Nature de l'objet en linguistique } \\
\text { La linguistique rencontre-t-elle devant } \\
\text { elle, comme objet premier et immédiat, } \\
\text { comme objet donné, un ensemble de choses } \\
\text { qui tombent sous le sens, comme c'est le cas } \\
\text { pour la physique, la chimie, la botanique, } \\
\text { l'astronomie, etc. ? } \\
\text { En aucune façon et à aucun moment : elle } \\
\text { est placée à l'extrême opposite des sciences } \\
\text { qui peuvent partir de la données des sens. } \\
\text { Une sucession de sons vocaux, par ex- } \\
\text { emple mer ( } m+e+r \text { ) est peut-être une unité } \\
\text { rentrant dans le domaine de l'acoustique, } \\
\text { ou de la physiologie; elle n'est à aucun titre, } \\
\text { dans cet état, une entité linguistique. } \\
\text { Une langue existe si à } m+e+r \text { s'attache une } \\
\text { idée. }\end{array}$ \\
\hline
\end{tabular}

Fonte: Manuscrito saussuriano (AdeS 372, p. 7), Écrits (BOUQUET ; ENGLER, 2002, p. 19-20) e Science du langage (AMACKER, 2011, p.83-84).

Nesse quadro, estabelecemos uma comparação entre o manuscrito saussuriano, a edição francesa Écrits de Linguistique Générale e a edição suíça Science du langage. Esse manuscrito é introduzido pelo questionamento "A linguística encontra diante dela um objeto dado, tal como as outras ciências?”. Esse questionamento que Saussure já se colocava muito anteriormente ao CLG será fundamental para a constituição da Linguística enquanto ciência. Entretanto, o efeito desse questionamento será sentido apenas posteriormente no seio do movimento estruturalista. A definição de um objeto para a Linguística já fazia parte das reflexôes silenciosas de Saussure. No entanto, quando essas reflexões tornam-se públicas, Saussure já havia se retirado e não ficou para ver o destino de suas ideias.

Nesse manuscrito, delimitamos com uma linha o que foi editado por ambas as ediçóes e sombreamos algumas divergências entre as edições do manuscrito, as quais serão analisadas em seguida.

Tendo em vista que a ediçẫo francesa não se propôs a editar as 
passagens barradas, no segundo quadro comparativo, apresentamos o manuscrito saussuriano e a edição suíça referente à passagem riscada que faz parte da página 7 do manuscrito (Quadro comparativo 2):

Quadro comparativo 2: Manuscrito saussuriano e Science du langage

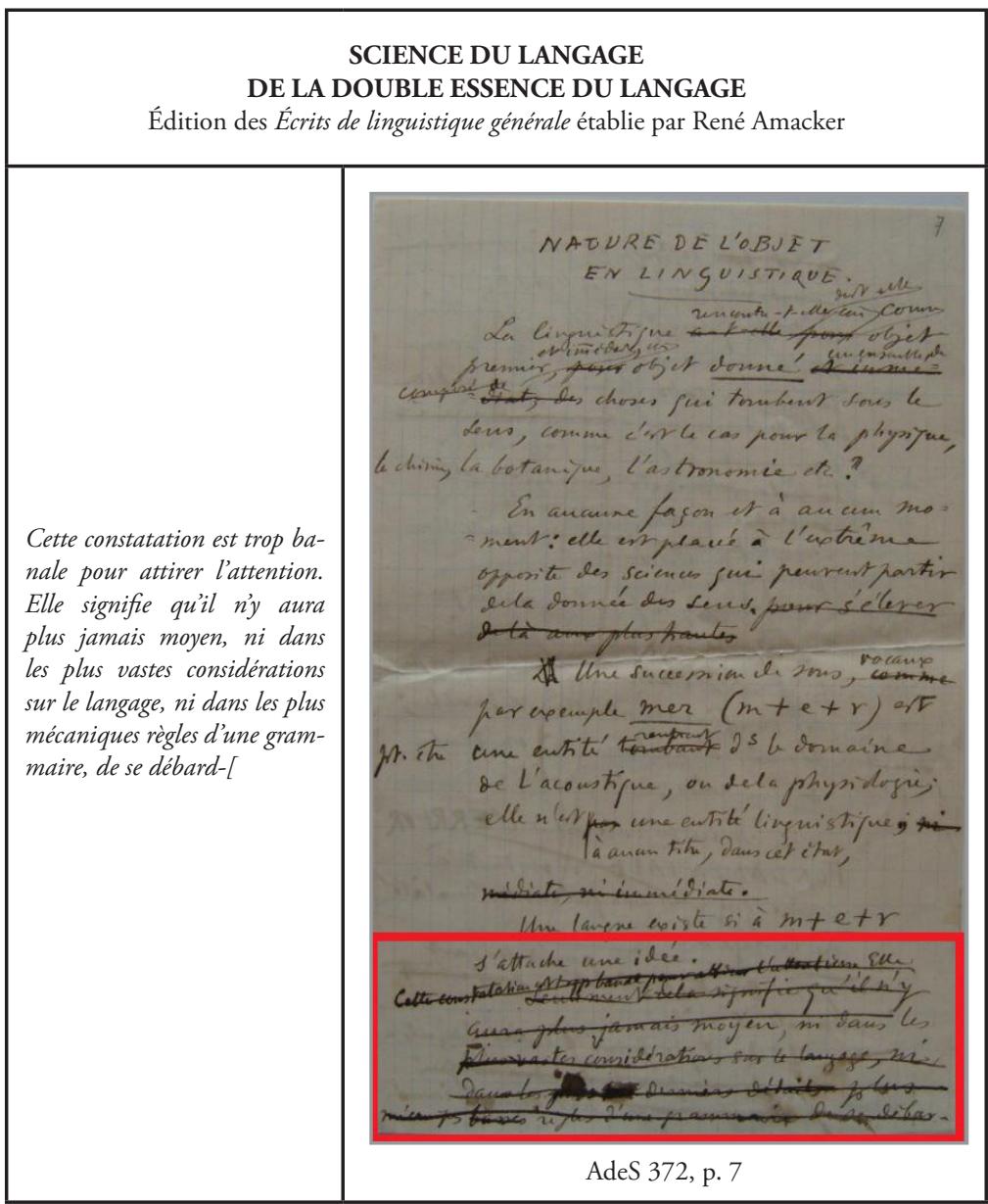

Fonte: Manuscrito saussuriano (AdeS 372, p. 7) e Science du langage (AMACKER, 2011, p. 84)

Nesse quadro comparativo, a passagem barrada pelo próprio autor parece produzir um efeito de apagamento. Para Saussure, tais consideraçôes 
são da ordem da obviedade e trata-se apenas de uma "constatação banal" que dispensa nossa atenção. Seria mesmo "une constatation trop banale"?

O manuscrito continua na página seguinte (8), onde boa parte da escrita é barrada. Trata-se de um efeito de paráfrase em que o autor volta-se sobre sua própria escritura para re-elaborá-la. Isso acontece nas páginas 8 e 9 do manuscrito. Entretanto, apenas uma pequena parte dessas duas páginas não foi barrada pelo autor. Vejamos o manuscrito (Quadro comparativo 3):

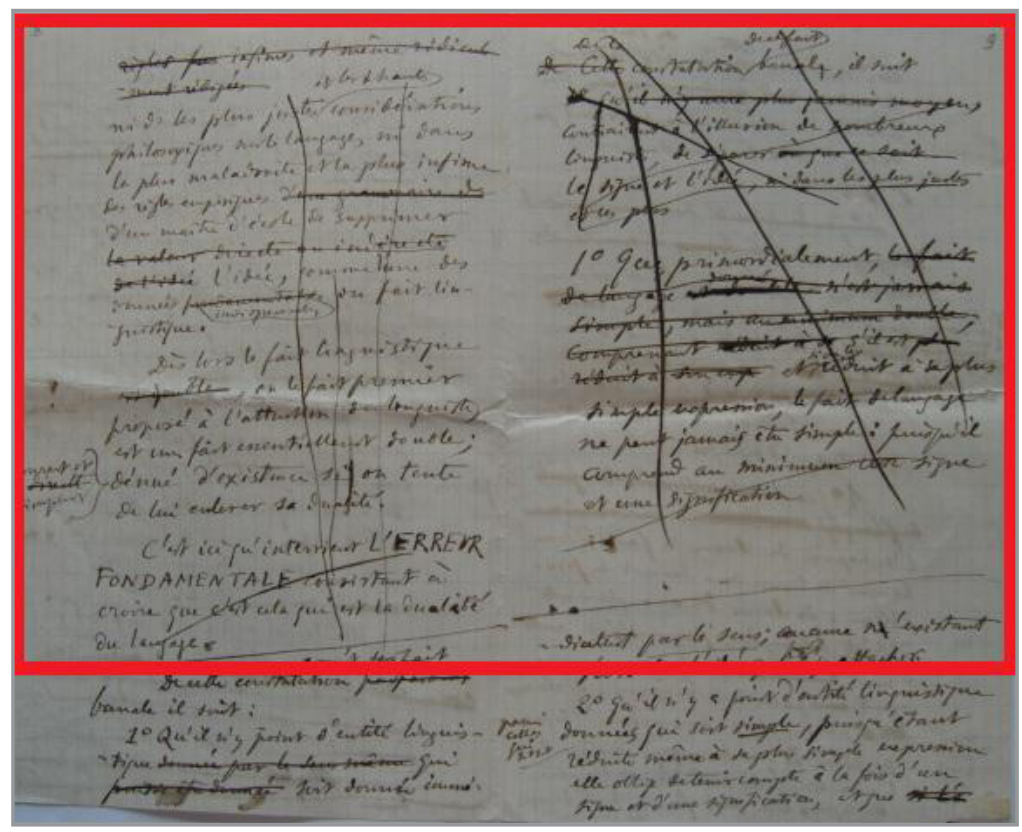

Quadro comparativo 3: Manuscrito saussuriano e Science du langage

Fonte : AdeS 372, p. 8-. 9 


\section{SCIENCE DU LANGAGE \\ DE LA DOUBLE ESSENCE DU LANGAGE}

Édition des Écrits de linguistique générale établie par René Amacker

[2.8] ni dans les plus justes et les plus hautes considérations philosophiques sur le langage, $n i$ dans la plus maladroite et la plus infime des règles empiriques d'un maître d'école, de supprimer l'idée, comme l'une des données indispensables du fait linguistique.

Dès lors le fait linguistique, ou le fait premier proposé à l'attention du linguistique, est un fait essentiellement double; purement et simplement dénué d'existence si on tente de lui enlever sa dualité.

C'est ici quintervient l'ERREUR FONDAMENTALE consistant à croire que c'est cela qui est la dualité du langage.
[2.9] De la constatation de ce fait banal, il suit :

$1^{\circ}$ qu'il n'y aura plus moyen, contrairement à l'illusion de nombreux linguistes, de séparer le signe et l'idée, ni dans les plus justes et les plus [

$1^{\circ}$ que, primordialement, et si on le réduit à sa plus simple expression, le fait de langage ne peut jamais être simple : puisqu'il comprend au minimum un signe et une signification [

Fonte: Manuscrito saussuriano (AdeS 372, p. 8- 9) e Science du langage (AMACKER, 2011, p. 84-85)

Nesse quadro, trouxemos apenas o manuscrito saussuriano e a edição suíça, pois se refere a, praticamente, duas páginas que foram barradas por Saussure. Nessas páginas barradas, o autor volta-se para o seria para ele uma evidência de que "le fait linguistique" constitui-se sobre uma dualidade e que o signo jamais poderia ser desvinculado da ideia a que está associado. Destacamos também, nessa passagem barrada, a veemência com que Saussure sustenta sua reflexão e a recorrência da expressão "ni dans les...".

No quadro seguinte, também referente às paginas 8 e 9, comparamos o manuscrito saussuriano e a pequena parte que foi editada por ambas as publicaçôes. Vejamos o quadro comparativo 4: 
Quadro comparativo 4: Manuscrito saussuriano, Écrits e Science du langage

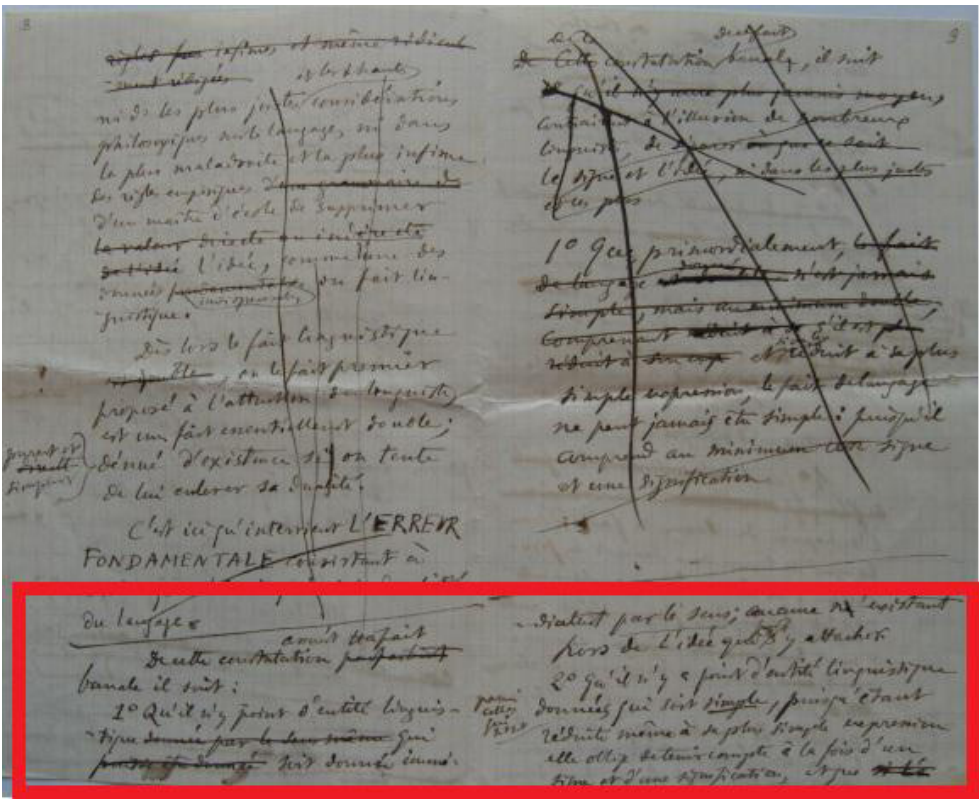

Fonte : AdeS 372, p. 8 - 9

\begin{tabular}{|c|c|}
\hline $\begin{array}{l}\text { ÉCRITS DE LINGUISTIQUE } \\
\text { GÉNÉRALE } \\
\text { Texte établi et édité par Simon Bouquet et } \\
\text { Rudolf Engler }\end{array}$ & $\begin{array}{c}\text { SCIENCE DU LANGAGE } \\
\text { DE LA DOUBLE ESSENCE DU } \\
\text { LANGAGE } \\
\text { Édition des Écrits de linguistique générale } \\
\text { établie par René Amacker }\end{array}$ \\
\hline $\begin{array}{l}\text { De cette constatation assurément tout à fait } \\
\text { banale il suit: } \\
1^{\circ} \text { qu'il n'y a point d'entité linguistique qui } \\
\text { puisse être donnée, qui soit donnée immédi- } \\
\text { atement par le sens; aucune n'existant hors de } \\
\text { l'idée qui peut s'y attacher; } \\
2^{\circ} \text { qu'il n'y a point d'entité linguistique par- } \\
\text { mi celles qui nous sont donnée qui soit simple, } \\
\text { puisque étant réduite même à sa plus simple } \\
\text { expression elle oblige de tenir compte à la fois } \\
\text { d'un signe et d'une signification, et que }\end{array}$ & $\begin{array}{l}\text { [2.8 en bas] De cette constatation assurément } \\
\text { tout à fait banale il suit: } \\
1^{\circ} \text { Qu'il n'y a point d'entité linguistique qui } \\
\text { soit donnée immé-[2.9 en bas]-diatement par } \\
\text { les sens; aucune n'existant hors de l'idée qui } \\
\text { peut s'y attacher. } \\
2^{o} \text { qu'il n'y a point d'entité linguistique par- } \\
\text { mi celles qui nous sont donnée qui soit simple, } \\
\text { puisque étant réduite même à sa plus simple } \\
\text { expression elle oblige de tenir compte à la fois } \\
\text { d'un signe et d'une signification, et que }\end{array}$ \\
\hline
\end{tabular}

Fonte: Manuscrito saussuriano (AdeS 372, p. 8 - 9), Écrits (BOUQUET; ENGLER, p. 20) e Science du langage (AMACKER, 2011, p. 85-86) 
Nessa parte, que é editada por ambas as publicaçóes, escrita posteriormente à passagem barrada, Saussure parece ter sintetizado aquilo que havia sido elaborado anteriormente e foi barrado. As numeraçóes, $1^{\circ}$ e $2^{\circ}$, parecem contribuir para esse efeito de síntese. Sobre as ediçóes do manuscrito, destacamos apenas a expressão "qui puisse être donnée", que sombreamos, que é linearizada na ordem da frase na edição francesa, mas que, no manuscrito saussuriano, havia sido barrada.

O manuscrito continua ainda na página 10, onde o autor continua a enumeração, até $4^{\circ}$. Nesse manuscrito, "Nature de l'objet en linguistique", o que Saussure sustenta é o que ele vai chamar de a dupla essência da linguagem, ainda que a terminologia, tal como a conhecemos a partir do CLG, não tenha sido ainda elaborada. Desse modo, entendemos que se trata de um manuscrito, de notas inacabadas, e é dessa perspectiva que deve ser compreendido. Para nós, o estudo dos manuscritos saussurianos permite compreender o processo de elaboração de conceitos-chave que contribuíram para a produçáo do conhecimento sobre a língua e estáo também inscritos na história da Linguística. 
Quadro comparativo 5: Manuscrito saussuriano, Écrits e Science du langage

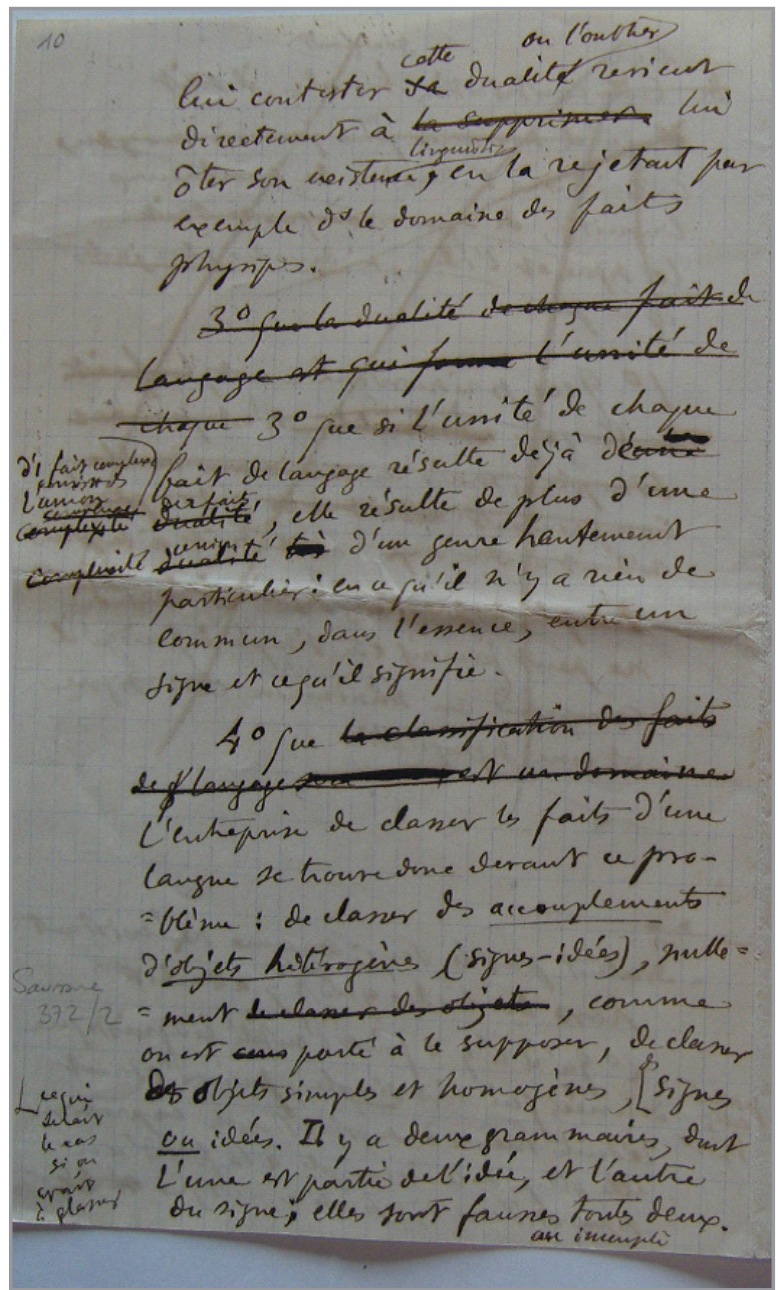

Fonte : AdeS 372, p. 10 


\begin{tabular}{|c|c|}
\hline $\begin{array}{l}\text { ÉCRITS DE LINGUISTIQUE } \\
\text { GÉNÉRALE } \\
\text { Texte établi et édité par Simon Bouquet et } \\
\text { Rudolf Engler }\end{array}$ & $\begin{array}{c}\text { SCIENCE DU LANGAGE } \\
\text { DE LA DOUBLE ESSENCE DU } \\
\text { LANGAGE } \\
\text { Édition des Écrits de linguistique générale } \\
\text { établie par René Amacker }\end{array}$ \\
\hline $\begin{array}{l}\text { lui contester cette dualité ou l'oublier revient } \\
\text { directement à lui ôter son existence linguis- } \\
\text { tique, en la rejetant par exemple dans le do- } \\
\text { maine des faits physiques; } \\
3^{o} \text { que si l'unité de chaque fait de langage } \\
\text { résulte déjà d'un fait complexe consistant dans } \\
\text { l'union des faits, elle résulte de plus d'une } \\
\text { union d'un genre hautement particulier : en } \\
\text { ce qu'il n'y a rien de commun, dans l'essence, } \\
\text { entre un signe et ce quìl signifie; } \\
4^{o} \text { que l'entreprise de classer les faits d'une } \\
\text { langue se trouve donc devant ce problème : de } \\
\text { classer des accouplements d'objets hétérogènes } \\
\text { (signes-idées), nullement, comme on est porté } \\
\text { à le supposer, de classer des objets simples et } \\
\text { homogènes, ce qui serait le cas si on avait à } \\
\text { classer des signes ou des idées. Ily a deux gram- } \\
\text { maires, dont l'une est partie de l'idée, et l'au- } \\
\text { tre du signe; elles sont fausses ou incomplètes } \\
\text { toutes deux. }\end{array}$ & 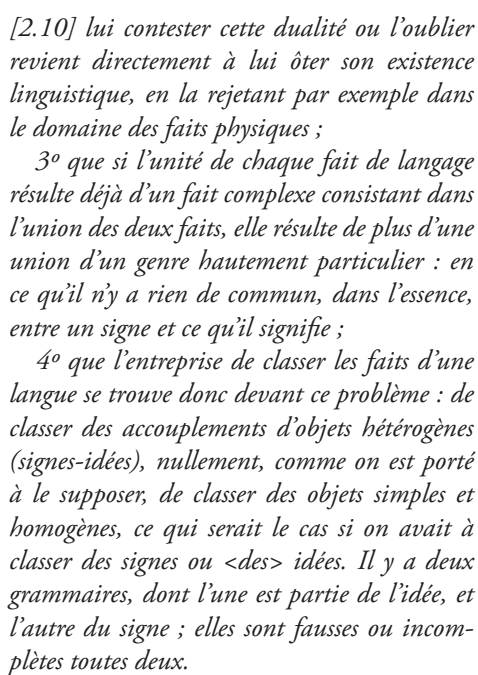 \\
\hline
\end{tabular}

Fonte: Manuscrito saussuriano (AdeS 372, p. 10), Écrits (BOUQUET; ENGLER, p. 20) e Science du langage (AMACKER, 2011, p.86)

A partir desses quadros comparativos, não nos propomos a fazer uma análise minuciosa do manuscrito, fizemos apenas apontar algumas reflexões iniciais acerca do gesto interpretativo do sujeito ao editar o manuscrito. Para isso, consideraremos dois tipos de passagens barradas e a forma como são editadas. Desse modo, os dois tipos de passagens barradas que estamos considerando são: 1) aquelas em que o autor, ao voltar-se sobre sua própria escritura, barra e propóe uma substituição; 2) aquelas em que as passagens são barradas produzindo um efeito de apagamento.

Em relação às passagens barradas do primeiro tipo - que são editadas por ambas as publicaçóes -, poderíamos considerar, em termos saussurianos, que há um desdobramento da palavra, de forma que a linearidade das relaçôes sintagmáticas, as quais se estabelecem no eixo da combinação, bifurca-se, fazendo ressoar as relaçóes associativas que se estabelecem no eixo 
da seleção. Na edição francesa, as passagens barradas são suprimidas e não há nenhuma referência às dificuldades que elas impóem ao trabalho de edição. Já na edição suíça, cada intervenção manuscrita que escapa à linearidade do texto é descrita em nota de rodapé, as quais não transcrevemos aqui.

Esse tipo de passagem barrada manifesta-se já nas primeiras linhas do manuscrito. Em meio a tantas retificaçóes por parte do autor, destacamos apenas uma divergência mais significativa entre as ediçóes do manuscrito. $\mathrm{Na}$ primeira frase que introduz o texto manuscrito, as ediçôes divergem no seguinte aspecto:

\begin{tabular}{|l|l|l|l|}
\hline Écrits & $\begin{array}{l}\text { La linguistique rencontre-t-elle } \\
\text { devant elle, comme objet } \\
\text { premier et immédiat, }\end{array}$ & un objet donné, & $\begin{array}{l}\text { un ensemble de } \\
\text { choses qui tombent } \\
\text { sous le sens }\end{array}$ \\
\hline $\begin{array}{l}\text { Science } \boldsymbol{d u} \boldsymbol{u} \\
\text { langage }\end{array}$ & $\begin{array}{l}\text { La linguistique rencontre-t-elle } \\
\text { devant elle, comme objet } \\
\text { premier et immédiat, }\end{array}$ & $\begin{array}{l}\text { comme objet } \\
\text { donné, }\end{array}$ & $\begin{array}{l}\text { un ensemble de } \\
\text { choses qui tombent } \\
\text { sous le sens }\end{array}$ \\
\hline
\end{tabular}

Essa diferença, que muda a sintaxe da frase, atribui a "objet donné" funçôes distintas. Nos Écrits, "objet donné" é o objeto direto do verbo "rencontre", ao passo que em Science du langage, o objeto do verbo "rencontre" passa a ser "un ensemble de choses". Essas divergências justificam-se pelas dificuldades que as passagens barradas e os acréscimos à borda do texto impóem e que demandam do editor um gesto interpretativo.

Em relação à página 8 do manuscrito, há uma única divergência entre as ediçôes. Trata-se do acréscimo da oração relativa "qui puisse être donnée" na linearidade do texto na edição francesa, expressão que é barrada no manuscrito. Isso parece-nos curioso, já que os editores optaram por não incluir as partes barradas. Em relação a essa passagem não há nenhuma proposta de substituição, ela é apenas barrada, produzindo um efeito de pagamento.

Já em relação às rasuras do segundo tipo, aquelas que produzem um efeito de apagamento, a linearidade do significante, que faz com que os sintagmas organizem-se na frase em uma mesma direção, náo permite que as palavras sejam desditas. Não é possível fazê-las voltar, mudando a sua direção, nem puxá-las de volta. Nesse manuscrito, há uma grande parte que foi barrada pelo próprio autor. Essas passagens barradas são parafraseadas 
ao longo do texto, de modo que o autor parece voltar-se sobre sua própria escrita, reelaborando-a.

Em relação à temática abordada nesse manuscrito, a natureza do objeto em Linguística, tem-se um tema que permeou as reflexôes de Saussure antes mesmo de ministrar o CLG. Nesse sentido, cabe ressaltar o efeito de eco que essa temática produz em relação ao CLG, especialmente ao Capítulo III, intitulado "Objet de la Linguistique". Sabemos que esse manuscrito náo serviu de fonte para os editores do CLG, mas propomos um quadro comparativo para ilustrar os efeitos metafóricos de uma formulação a outra, pois ambas as obras são atribuídas ao mesmo autor, que não as publicou.

Quadro comparativo 6: Écrits e CLG

La linguistique rencontre-t-elle devant elle, comme objet premier et immédiat, un objet donné, un ensemble de choses qui tombent sous le sens, comme c'est le cas pour la physique, la chimie, la botanique, l'astronomie, etc. ?

En aucune façon et à aucun moment : elle est placée à l'extrême opposite des sciences qui peuvent partir de la donnée des sens.

\section{Écrits de Linguistique Générale}

Quel est l'objet, à la fois intégral et concret de la Linguistique? La question est particulièrerment diffícile; nous verrons plus tard pourquoi ; bornons-nous ici à faire saisir cette difficulté.

D'autres sciences opèrent sur des objets donnés d'avance et qu'on peut considérer ensuite à différents points de vue ; dans notre domaine, rien de semblable.

\section{Cours de Linguistique Générale}

Fonte: Écrits (BOUQUET; ENGLER, 2011, p. 10-20 ) e CLG (SAUSSURE, 1995, p. 23)

Esquema de comparação 1: efeitos metafóricos

La linguistique rencontre-t-elle devant elle, comme objet premier et immédiat, un objet donné, un ensemble de choses qui tombent sous le sens,

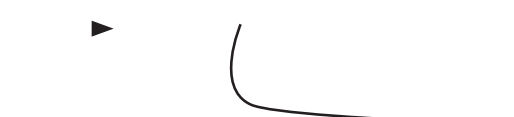

Quel est l'objet, à la fois intégral et concret de la Linguistique?
Comme c'est le cas pour la physique, la chimie, la botanique, l'astronomie, etc. ?]

En aucune façon et à aucun moment : elle est placée à l'extrême opposite des sciences qui peuvent partir de la donnée des sens.

[D'autres sciences] opèrent sur des objets donnés d'avance et qu'on peut considérer ensuite à différents points de vue ;

dans notre domaine, rien de semblable.

Fonte: nossa. 
O questionamento sobre o objeto da Linguística, que introduz o manuscrito, e a relação desse objeto com a cientificidade mantém-se também no CLG. Nos Écrits, o questionamento já aponta, de antemão, a comparaçáo entre o objeto da Linguística e o objeto de outras ciências, enquanto no CLG a comparação com outras ciências é mencionada na resposta à pergunta posta. Em ambos os casos, a Linguística é colocada ao lado de outras ciências que, enquanto tal, possuem um objeto bem definido. A Linguística, por seu lado, assim como as outras ciências, também possui um objeto. Entretanto, a natureza do objeto da Linguística não se constitui tal como o objeto das outras ciências. Desse modo, o que ressaltamos na comparação entre esses dois fragmentos é a importância de definir um objeto como condição de cientificidade.

A proposta de estabelecer uma relação entre o CLG e o manuscrito de "De la double essence du langage", que não serviu de fonte para a edição do CLG, justifica-se na medida em que entendemos que a heterogeneidade do corpus saussuriano pode contribuir para a compreensão do legado do mestre genebrino. O questionamento "qual é o objeto da Linguística?", que contribuiu para colocar a Linguística entre as ciências, já fazia parte das reflexóes saussurianas e antecede o CLG, mas seu efeito foi sentido apenas posteriormente e permanece ainda hoje produzindo seus efeitos de sentido.

\section{Uma conclusáo ainda inconclusa}

Saussure, não é tão simples assim! (GADET; PÊCHEUX, 2010, p. 58).

Caro leitor, neste artigo buscamos compreender a complexidade do empreendimento saussuriano sobre a importância da definição de um objeto para a Linguística, ainda que nossos apontamentos sejam apenas embrionários. Desse modo, procuramos compreender a importância da leitura realizada sobre o CLG no seio do movimento estruturalista e que contribuiu para alçar a Linguística como ciência, tomando como referência o corte epistemológico promovido a partir da definição de um objeto. No que toca aos manuscritos, neste estudo apresentamos apenas algumas reflexóes iniciais que podem ajudar-nos a compreender a constituiçấo do gesto interpretativo do sujeito ao editar um manuscrito. Partimos do pressuposto de que os manuscritos constituem-se referencial de uma reflexão inconclusa que é tornada pública por meio de um processo de ediçáo. Entretanto, a 
edição de tais manuscritos está pautada sobre critérios que produzem um efeito de objetividade ao gesto do sujeito editor. O legado saussuriano está fadado a essa incompletude dos manuscritos, que nunca se tornaram um texto final, bem como à forma como temos acesso às reflexóes saussurianas, as quais são mediadas por um processo de edição, seja o do CLG, seja o dos Écrits.

Ainda que o CLG seja apontado pela sua náo fidelidade ao pensamento saussuriano sob vários aspectos, no que toca ao objeto da Linguística essa é uma preocupação que toma as reflexóes do mestre genebrino. Saussure opta por desafiar a dificuldade de responder essa questão que os seus contemporâneos procuravam evitar. Ao definir qual é o objeto da Linguística e de que natureza é esse objeto, Saussure promove um corte epistemológico, ainda que esse corte venha a constituir-se apenas posteriormente. No momento em que Saussure questiona-se sobre o objeto da Linguística, seus contemporâneos parecem tê-lo deixado sozinho com seus problemas... como diria Benveniste (2005). Ao encontrar uma resposta para tal questionamento, definindo a língua como objeto da Linguística e a natureza desse objeto, desde então, Saussure nunca mais esteve sozinho com seus problemas. Passado meio século de publicaçáo do CLG, em 1963, Benveniste (2005), o mais saussuriano dos linguistas (NORMAND, 2006), considerava que:

\footnotetext{
[...] abarcando com o olhar esse meio século decorrido, podemos dizer que Saussure cumpriu bem o seu destino. Além da sua vida terrena, as suas ideias brilham mais longe do que ele teria podido imaginar, e esse destino póstumo se tornou como uma segunda vida, que se confunde para sempre com a nossa (BENVENISTE, 2005, p. 49).
}

Agora, passado mais meio século desde essa afirmação de Benveniste e mais de cem anos dos escritos de Saussure, as palavras de Benveniste, assim como o legado saussuriano, continuam atuais, e a Linguística já não consegue mais se desprender de Saussure.

\section{REFERÊNCIAS}

AUROUX, Sylvain. A questáo da origem das línguas, seguido de A historicidade das ciências. Tradução M. P. G. Joanilho. Campinas: RG, 2008.

BENVENISTE, Émile. Problemas de Lingüística Geral I. Tradução M. 
de Glória e M. L. Néri. 5. ed. Campinas: Pontes, 2005.

Problemas de Lingüística Geral II. Tradução E. Guimarães et al. Campinas: Pontes, 1989.

BOUQUET, Simon. Après un siècle, les manuscrits de Saussure reviennent bouleverser la linguistique. Texto!, 2005. Disponível em: $<$ http:// www.revue-texto.net/Saussure/Sur_Saussure/Bouquet_Apres.html>. Acesso em: fev. 2014.

BULEA, Ecaterina. O signo em Ferdinand de Saussure: um campo chave para a chave dos campos. Tradução M. Bagno. Revista Traduzires, v. 2, n. 1, 2013, p. 31-53.

GADET, Françoise. Saussure: une science de la langue. Paris: Presses Universitaire de France, 1996.

; PÊCHEUX, Michel. A língua inatingível: o discurso na história da lingüística. Tradução B. Mariani e M. E. C. de Mello. Campinas: Pontes, 2010.

NORMAND, Claudine. Saussure. Tradução A. de Alencar e M. Diniz. São Paulo: Estação Liberdade, 2009.

Saussure-Benveniste. Revista Letras, Santa Maria, n. 33, jul.-dez. 2006. Disponível em: <http://cascavel.ufsm.br/revistas/ojs-2.2.2/index. php/letras/issue/view/653/showToc>. Acesso em: fev. 2014.

PAVEL, Thomas. A miragem linguística: ensaio sobre a modernização intelectual. Traduçáo E. Orlandi, P. de Souza e S. S. Guimarães. Campinas: Pontes, 1990.

SAUSSURE, Ferdinand de. Curso de linguística Geral. 27. ed. Organizado e editado por Charles Bally e Albert Sechehaye. São Paulo: Cultrix, 2006.

Cours de Linguistique Générale. Édition critique preparée par Tullio de Mauro. Paris: Payot \& Rivages, 1995.

Escritos de Linguística Geral. Organizados e editados por Simon Bouquet e Rudolf Engler. São Paulo: Cultrix, 2012.

Écrits de linguistique générale. Organisés et edités par Simon Bouquet et Rudolf Engler. Paris: Gallimard, 2002. 
. Sciences du langage - De la double essence du langage, Édition des Écrits de linguistique générale établie par René Amacker. Genève: Librarie Droz, 2011.

SÉRIOT, Patrick. Limites, bordas e normas: a delicada constituição do objeto de conhecimento em ciências humanas. Tradução A. E. Scherer e M. I. S.Costa. Organon, Porto Alegre, n. 59, v. 30, jul.-dez.2015, p. 55-70. Disponível em: <http://www.seer.ufrgs.br/organon>. Acesso em: dez. 2015.

SILVEIRA, Eliane. As marcas do movimento de Saussure na fundação da Linguística. Campinas: Mercado de Letras, 2007.

SOFIA, Estanislao. Quelques problèmes philologiques posés par l'oeuvre de Saussure. Langages, n. 185, 2012. Disponível em: <http://orbi.ulg.ac.be/ handle/2268/140844>. Acesso em: fev. 2014. 